\title{
PERCEPTIONS OF FAMILY HURDLES AMONG EMERGING ADULTS: A PRELIMINARY STUDY ABOUT RESILIENCE IN THE INDONESIAN FAMILY
}

\author{
Annastasia Ediati, Salma Salma, Dian Veronika Sakti Kaloeti \\ Faculty of Psychology, Diponegoro University \\ Jl. Prof. Soedarto, SH, Kampus Undip Tembalang, Semarang, Indonesia 50275 \\ aediati@gmail.com
}

\begin{abstract}
Family resilience is an essential skill for family members to deal with problems in their families. It is a condition in which a family able to adapt and successfully cope with stress, either now or in the future. Emerging adults are faced with a number of development tasks that focus on career development, independence, and building a family. The study aims to explore to what extent emerging adults in Indonesia interpret the problems in their families and describe their self-efficacies in dealing with these problems. The study participants comprised 1,010 emerging adults (aged 18-25 years old) who studied at various universities in Indonesia. They were approached using a snowball sampling technique. An indigenous psychology approach was used in the study and data were analyzed qualitatively. The results of data analysis showed that emerging adults in Indonesia positively interpreted the problems in their families. In addition, the majority of participants indicated of having self-efficacy towards problem-solving. We applied the sense of coherence concept to explain positive meanings and self-efficacy that have a positive impact on emerging adults in developing into resilient individuals in responding to the challenges of developmental tasks in the transition to adulthood.
\end{abstract}

Keywords: self-efficacy; emerging adult; positive meaning; family resilience; a sense of coherence

\begin{abstract}
Abstrak
Resiliensi keluarga merupakan kemampuan esensial yang dibutuhkan untuk dapat menghadapi masalah yang dialami secara kolektif oleh setiap anggota keluarga. Resiliensi keluarga adalah suatu kondisi di mana keluarga mampu beradaptasi dan berhasil melalui stres, baik di saat sekarang maupun waktu-waktu berikutnya. Emerging adults dihadapkan pada sejumlah tugas perkembangan yang berfokus pada perkembangan karier, kemandirian, dan membangun keluarga baru. Penelitian ini bertujuan untuk mengeksplorasi bagaimana emerging adults di Indonesia memaknai permasalahan yang dihadapi di dalam keluarga serta efikasi diri mereka dalam menghadapi masalah tersebut. Partisipan penelitian ini terdiri dari 1.010 emerging adults (usia 18-25 tahun) yang menempuh studi di berbagai universitas di Indonesia dengan menggunakan teknik snowball sampling. Pendekatan psikologi ulayat digunakan dalam penelitian ini dan data dianalis secara kualitatif. Hasil analisis data menunjukkan bahwa emerging adults di Indonesia mampu memaknai secara positif masalah yang dihadapi. Hal ini juga didukung oleh efikasi diri terhadap pemecahan masalah yang ditujukan oleh sebagian besar partisipan. Konsep sense of coherence diterapkan untuk menjelaskan pemaknaan positif serta efikasi diri yang berdampak positif bagi emerging adults dalam berkembang menjadi individu yang resilien dalam menjawab tantangan tugas perkembangan di masa transisi menuju dewasa.
\end{abstract}

Kata kunci: efikasi diri; emerging adults; pemaknaan positif; resiliensi keluarga; sense of coherence

\section{INTRODUCTION}

Family plays an important role in developing the mental health of its members. Family is the first environment, in which children are introduced, socialized, and has an important influence on children's development. Through family, children learn to respond to others and know themselves. Biological and psychological attachments lead the families to interplay their mental health significantly (Ennis \& Bunting, 2013).

A number of studies suggest, that conflicts between family members, such as divorce, 
sibling rivalry, domestic violence have deleterious impact on various health issues, as well as psychological distress, depression, anxiety, and even a number of maladaptive behaviors, such as aggressiveness in children and adolescents or infidelity of husband or wife (Kolak, Wade, \& Ross, 2018; Myklestad, Røysamb, \& Tambs, 2012; Ryan, O'Farelly, \& Ramchandani, 2017; D'Onofrio \& Emery, 2019). On the other hand, a number of studies have revealed that the role of the family has a positive impact on the mental health of family members (Chacko et al., 2009; Gyamfi et al., 2009; Hoagwood et al., 2010). Further, this model is found progressively more grounded in families living amidst collectivist societies, including Indonesia (Du, Li, Lin, \& Tam, 2015; Fitriyasari, Yusuf, Nursalam, Tristiana, \& Nihayati, 2018).

In each developmental phase, an individual has to deal with tasks and crises, also when someone enters a developmental period, the age varies of 18-25 years. It is known as the stage of emerging adulthood. This phase is the stage of transition from adolescence to adulthood (Arnett in Papalia, Olds \& Feldman, 2009). The development tasks commonly include (1) identity exploration; (2) instability; (3) self-focus; (4) feeling in between two phases, adolescents and adults; and (5) trying out various opportunities (ages of possibilities). In addition, the emerging adult confronts a number of other psychological problems, such as the emergence of anxiety and other negative emotions towards careers and life partners, maladaptive behavioral disorders such as drinking alcohol or narcotics (Merikangas et al., 2010). Michaud and Fombonne (2005) found that there were three factors that triggered the crisis in the era of emerging adulthood, namely: (1) increase of pressure on education and occupation, because of lack in education and jobs availability; (2) increase unemployment number; and (3) social changes, include weakened function and role of the family. It can be concluded, that in early adulthood, individuals or emerging adults are facing more complex developmental problems and tasks than in adolescence. Therefore, in order to be able to get through the tasks and crises, the emerging adults urgently need the family role.

The role of the family is crucial for emerging adults in growing into an individual adult. Several studies have found that the development from the child to adolescents and adults phase is strongly influenced by the internalization of the values, instilled by families and communities. Families play a role in restructuring emotions and cognition so that emerging adults able to strategically cope, overcome, and master the problems (Luthar, 2006; Ungar, 2013). Resilience is a capacity of a system (individual, family, or other systems) to well adapt to the challenges or difficulties, that are threatening the function, survival, and development of the system (Masten, 2018). Family resilience is a condition in which a family is able to adapt and succeed in coping stresses, in the present and subsequent times (Hawley \& DeHaan in Kalil, 2003). Resilience is formed from the interaction between risk factors and protective factors (Kalil, 2003). Risk factors can potentially cause difficulties. Protective factors are strengthening the individual or family in confronting difficulties. The family adopted belief system, family organization patterns and communication process/ problem solving are suggested as supporting factors for the family resilience (Walsh, 2003). Nevertheless, in reality, there are problems, occurring in the family, like a dysfunctional family, which results in a lack of emotional support, and has an impact on child maladaptive behavior or criminality hereafter (González-Gadea et al., 2014). Furthermore, poor relationships with mothers and fathers, lack of parental support for emerging adults in overcoming problems, a cold family atmosphere, have an impact on the poor mental health of 
emerging adults (O'Rourke, Halpern, \& Vaysman, 2018). These components can cause less help for the process of family strength.

The occurring problems in the family are perceived differently by each family member. A problem perceived by one family member is not necessarily a problem for other members. One family member could perceive an incident as a tough problem to deal with, while another member may assume that the incidents are an ordinary problem. Furthermore, families with the ability to survive in facing difficult situations will form collective resilience as well. Family resilience has a positive impact on each family member, in dealing with the experienced stressors. Resilient families show supports gives, and reciprocate among the members. So the family integrity and harmony can be maintained (Valdez, Chavez, \&Woulfe, 2012). Diversity in perceiving problems among family members is the background to implement this research. This research focuses on the emerging adults in perceiving problems, confronted by the family. Some problems are also necessary for resilience building (Walsh, 2003).

Rising grown-ups are stood up to with various formative errands, that emphasis on vocation autonomy and building another family. Then again, the preparation of rising grown-ups in completing undertakings is as yet a different issue. Wood et al. (2018) found that a lack of confidence in undergoing developmental tasks properly would lead to failure in passing through the developmental tasks expected by the community. Furthermore, the value inculcation in the family contributes significantly to the ability to emerge adults to respond to the development task (Luecken \& Gress, 2010). Therefore, this study explores the meaning of family hurdles in emerging adults' point of view, and their self-efficacy in perceived the ability of their family to solve the problems. For
Indonesian, family plays an important role in building the mental health of its members. The adversity faced by family and problem solving specifically applied by Indonesian families need to be a particular concern for the psychological science in Indonesia. This study is a preliminary study, to get a picture of family resilience based on Indonesian emerging adult perspective.

\section{METHOD}

\section{Research approach}

This exploration utilizes a grounded hypothesis with a constructivist approach, a methodology intends to increase a ground hypothesis and dynamic pattern, concentrating on accentuation on the importance of the participant's answers (Charmaz in Creswell, 2012).

\section{Participants}

1,010 participants were involved in this research. Participants' recruitment is conducted with a snowball sampling method. Participants are students of 80 universities in Indonesia, aged 18-25 years old $(\mathrm{M}=21 \pm 1,3$ years; $23 \%$ male and $77 \%$ female). Table 1 contains the demographic data of the participants.

\section{Data Collection}

The indigenous psychological approach was used in this study to get a contextual picture of understanding the problem faced by the family, in emerging adults in Indonesia. An open-ended questionnaire was compiled based on the concept of the resilience of Walsh (2003) and distributed through Google form. The questions were: (1) "What difficulties are you / have faced in your family?" (2) "What did you learn from the difficulty? "(3)" Are you sure that the difficulty will be overcome? Explain your answer! "

\section{Data analysis}

In this study, the data were analyzed qualitatively, by searching each keyword from the participants' answers and tabulating 
the keywords into quantitative data (Kim \& Park, 2008).

\section{RESULTS AND DISCUSSION}

\section{Characteristics of Participant}

The demographic analysis data includes ethnic background, family income, parent's marital status and years of study, as can be seen in Table 1. In general, the majority $(62.97 \%)$ of participants were Javanese. Ethnicities from outside Java also participated, namely, Batak and Minang ethnic. $43.17 \%$ of total participants had a family income below IDR 2,500,000, or almost equivalent to the regional minimum wage of Central Java. Most participants $(82.7 \%)$ have parents in a marriage relationship. The proportion of participants according to years of study is relatively balanced in number.

Table 1.

Characteristics of Participants $(\mathrm{N}=1,010)$

\begin{tabular}{lcc}
\hline \multicolumn{1}{c}{ Characteristics } & f & \% \\
\hline Ethnicities & 636 & 62,97 \\
Javanese & 65 & 6.44 \\
Bataknese & 64 & 6,34 \\
Sudanese & 47 & 4,65 \\
Minangnese & 198 & 19,60 \\
Others & & \\
Family income (Rupiah) & 136 & 13,47 \\
1,000,000 & 300 & 29,70 \\
1,000,000 - 2,500,000 & 284 & 28,12 \\
2,500,000-5,000,000 & 290 & 28,71 \\
5,000,000 & & \\
Parental marital status & 835 & 82,67 \\
Married & 76 & 7,52 \\
Divorced & 99 & 9,80 \\
Death of spouse & & \\
Years of study & 262 & 25,94 \\
First & 248 & 24,55 \\
Second & 227 & 22,48 \\
Third & 207 & 20,50 \\
Fourth & 66 & 6,53 \\
Fifth and so forth & &
\end{tabular}

\section{Family's Hurdles}

This study found that the most problems faced by participant's families are family financial problems, particularly education costs, debt, the problem in the business of their parents or family bankrupt, parents' retirement, and parental job loss. Relationship issues among relatives are additionally looked by numerous participants, likewise misalignment throughout everyday life (philosophy) among relatives, parent-child conflict, marital conflict, long-distance marriage, separate, divorce, single parent, parental remarriage and adjustment of a new family member. Most health problems, found in the participant's family are accidents of family members, suffering from chronic illness, and terminal illness. Some problems relate to factors outside the nuclear family, include problems with extended families, neighbors, communities, law enforcement agencies (crime and imprisonment), and natural factors (natural disasters). In addition, the death of family members (parents, siblings), was also mentioned as a family problem. Furthermore, problems experienced by participants' families can be seen in Table 2 below.

Table 2.

Family's Hurdles

\begin{tabular}{|c|c|c|}
\hline Categories & f & $\%$ \\
\hline Financial problem & 491 & 73,07 \\
\hline $\begin{array}{l}\text { The interpersonal problem } \\
\text { in the family }\end{array}$ & 213 & 31,70 \\
\hline Health problem & 76 & 11,31 \\
\hline $\begin{array}{l}\text { Problem related to people } \\
\text { outside the nuclear family }\end{array}$ & 64 & 9,52 \\
\hline Death of a family member & 14 & 2,08 \\
\hline
\end{tabular}

\section{Meaning of the Problem}

In most cases, participants perceived the problem internally and externally. Internally, $37.42 \%$ of participants interpreted the problem as an approach to construct a more mature cognitive process. These are the statements, conveyed by participants: 
Participants 1 (P1) and Participant 16 (P16)

"Everyone has their problems, although many people are better at financial, maybe they have tougher problems, without me knowing it." (P1)

"No matter how good the family conditions are, they have challenges/ temptation, which can unexpectedly happen" (P16)

$26.53 \%$ of participants thought that the problems they faced could foster their spirituality (P32 and P87), 20.97\% of participants considered the problems as valuable lessons for making better decisions in the future (P114 and P121). Externally, $15.07 \%$ of participants interpreted the problems as a way to strengthen the relationships among the family members (P55 and (P113).

"I learned about the meaning of gratitude, being thankful for all the difficulties I found up in my age, I'm sure God never left His children, learn to be independent, more independent than my peers, learn to be responsible, learn to be more mature in facing the problem, learn to rise in any circumstances." (p32)

"Can always be grateful to God, because with gratitude to God, everything is fulfilled (by God) and everyone has their own fortune" (P87)

"Choosing the right life partner with the same vision, pious and cooperate to build a good family. Bad or good of the family depends on its members." (P114)

"What my parents gave me as an example are learn to keep on believing, that fortune has been arranged by God, live in simplicity, no matter how difficult (the finance) is, do not owe. In the future, I want to run a business, so I can get additional income and able to share it with people in need." (P121)
"Families are a team, every member has to trust each other, take care of each other and tolerance for each other. If there is a problem then solve the core problem, sit down and discuss it together. No matter how big and difficult the problems are, (family/its members) has to fix it. Forgiveness and (give) second chance are important." (P55)

"Pay more attention to mom. Because in the past I tend to pay less attention, care (to mother). Now, I more often listen to mom, when she needs something to share or complain." (P113)

\section{Self-efficacy in Accomplished the Family's Hurdles}

Most (79\%) of participants believe, they are able to solve the problems. On the other hand, only $5 \%$ of participants thought that the problems are difficult to be overcome (P21), and the rest (16\%) were neutral. Several factors, affecting beliefs, originate from outside (external) and inside (internal) the participants. Around $75 \%$ (P105) of participants' affirmed that external factors such as supports from each family member are able to increase their positive thought toward the problems. About 25\% of participants believe in the importance of financial stability, even though the problems always exist (P94). Internal factors include cognitive reframing and active coping. Approximately, $77 \%$ (P81) of participants undertake the cognitive reframing. They change their point of view of a problem, into a more positive view. Furthermore, 23\% (P23) of participants tried to identify and solve the problems.

"Mom and Dad are 64 years old, it's too late to improve (fix the problem). Moreover, it is difficult for both, them, to accept the past and endure each other's mistakes" (P21)

"Our family (member) is supporting each other and understand the condition, happening at the time" (P105) 
"So far it (problem) can still be overcome, although have to borrow some (money) from other people first" (P94)

"Based on my family experience, (we just faced) only ordinary difficulties, which also faced by many other families. But there is always a possibility, that unexpected thing will happen, either it will worsen or alleviate the problem. "'(P81)

"My brothers and I are hard workers. We want to succeed in overcoming our family's economic difficulties and make our parents happy" (P23).

This study aims to identify the meaning of family hurdles in emerging adult's points of view and their self-efficacy toward their family issues in which we believed will give the family resilience picture. A number of unique problems in the family were found in this study. Most of the emerging adults, involved in this study $(73.07 \%)$, consider that financial problems are the most challenging problem, faced by the family. However, only $43.17 \%$ of participants have an income equivalent to or lower as the regional minimum wage. This indicates, that family income does not necessarily predict the occurred financial problems. In line with this finding, a number of studies have found that perceptions of financial difficulties are significantly positively correlated with the level of psychological distress in emerging adults (Dunn et al., 2008; Richardson, Elliot, Roberts, \& Jansen, 2017).

This study found that emerging adults in Indonesia are able to develop positive meanings thorough their family's' adversity. Ryff (2014) argues that positive meaning has implications for self-efficacy in dealing with problems. In line with this, the majority $(75 \%)$ of participants in this study expressed confidence in the family's ability to solve the problems. Furthermore, Valdez, Lim, and Parker (2015) suggest that positive meaning and self-efficacy determine the ability to deal with crises in youth. Ryff and Singer
(2006) found that positive meanings encourage individuals to be responsible for unraveling (active coping), and not just avoiding the problem (flight coping).

In particular, Walsh (2003) discusses the sense of coherence to describe positive meanings and its implications for families' efficacy and active coping in dealing with the problems. A sense of coherence is defined as characterized to what degree, an individual can decipher his capacity positively and confidently to deal with the problems, wherein the ability involves mental processes, both, personally and environmentally support (Eriksson, 2005). The role of sense of coherence in this study is indicated through positive meanings carried out by emerging adults both internally and externally, so it built the high self-adequacy, that empower them to solve the problems. This result is in line with the research result conducted by Konaszewski, Kolemba, and Niesiobędzka (2019). Research recommends that sense of coherence and self-efficacy correlate with the problem and emotional-oriented coping stress, whereas the low sense of coherence and self-efficacy are associated with avoidance coping stress.

Furthermore, this study found that emerging adults construe problems internally and externally. The first internal meaning is to build thought processes, and in that process, participants try to focus more on the positive rather than negative consequences of the difficulty. Moreover, Streb, Haller, and Michael (2014) found that the sense of coherence is associated with resilience. The presence of a sense of coherence helps individuals to wave facing problems, reestablish better social and psychological functions, and even offer ascent to posttraumatic growth in individuals, experienced trauma (Ragger, HieblerRagger, Herzog, Kapfhammer, \& Unterrainer, 2019; Veronese \& Pepe, 2014). 
Several kinds of literature expose that the role of the family is an essential factor for emerging adults to respond positively to the challenges. The essential family roles among others are socioeconomic conditions, parental support in various viewpoints in children's lives, the culture that develops in the family, norms that are explicitly applied in the family, and parenting styles (Fingerman, 2017; Roest, Dubas, \& Gerris, 2009). Especially, in the 21 st century, time for technology and social media develop rapidly, the role of the family in encouraging children to be adaptive becomes critical. Parental guidance surely has a greater impact on the process of children's socialization in the real world (Arnett, 2015). Cross-cultural research about emerging adults, conducted in Turkey and the United States found that culture influences differences in points of view and life of emerging adults in each country. The emerging adult in the United States, living with individualistic culture, growing in megapolitan cities shows more independence, compared to emerging adults in Turkish culture. Socioeconomic differences and strong pronounce of religious and cultural values in Turkey lead to the necessity of higher social support and tendencies to continually depend on extended family. In addition, in Turkey, the role of the original family is still strongly existing, after emerging adults decide to get married. On the contrary, this does not happen in the United States. The independence, that needs to be achieved by emerging adults in the United States before they decide to get married, is suspected to be a factor in postponing marriage (AycicegiDinn \& Kagitcibasi, 2010). In Indonesia, the role of families in encouraging emerging adults to be mature in facing life challenges is very crucial. Indonesia is a collectivist country with strong emphasized cultural values. A study conducted on adolescents, who grew up in ex-localization in Indonesia, emphasize the needs of family role in externalizing bad values, resulted from localization, and internalize good values, replacing the bad values, and think about responding the developmental task challenges (Hasanah, Susanti, \& Panjaitan, 2019).

Moreover, the findings of this study have several limitations, to be exact: (1) this study uses online data collection methods. Participants who are less technologically literate or do not have access to social media or the internet, could not be involved or participate in this study. So the description of their family problems are still unable to be explored; (2) the majority of participants are Javanese female. It is still less exactly known, how male participants view problems in their families. Less male participation in this study shows probably an ignorance attitude or thought of taboo to share information about family problems. The reason for this less male participation needs to be examined in further study. Future studies are expected to involve more participants from various non-Javanese ethnic groups, inter-ethnic families, and examine family problems based on different stages of the family cycle.

\section{CONCLUSION}

The results of this study showed that the majority of emerging adults have positive meanings about their family hurdles. It followed by self-efficacy toward the problems. Also, it can be concluded that emerging adults have a sense of coherence. The crisis experienced by an emerging adult can be interpreted as something positive, that can be used as a booster in dealing with other severe problems. The role of sense of coherence and self-efficacy, owned by emerging in overcoming their families' problems indicates that emerging adults are resilient individuals. The families play roles in helping emerging adults to interpret positively, built self-efficacy, and encourage the establishment of resilience in facing life difficulties. 


\section{ACKNOWLEDGMENT}

This research is funded by the Ministry of Research, Technology and Higher Education DRPM in the Higher Education Basic Research scheme (257-47 / UN7.P4.3 / PP / 2019). The researcher would like to thank research assistants Valentino Marcel Tahamata, S.Psi, and Ayu Kurnia, S.Psi and all the participants in this study.

\section{REFERENCES}

Arnett, J. J. (2015). Socialization in emerging adulthood: From the family to the wider world, from socialization to self-socialization. In J. E. Grusec, \& P. D. Hastings, Handbook of socialization (pp. 85108). New York, NY: Guilford Press.

Aycicegi-Dinn, A., \& Kagitcibasi, C. (2010). The value of children for parents in the minds of emerging adults. Cross-Cultural Research, 44(2), 174-205.

Creswell, J. W. (2012). Qualitative inquiry \& research design: Choosing among five approaches ( 2 nd ed.). Thousand Oaks, California, CA: Sage Publications, Inc.

Chacko, A., Wymbs, B. T., Wymbs, F. A., Pelham, W. E., Swanger-Gagne, M. S., Girio, E., ... O'Connor, B. (2009). Enhancing traditional behavioral parent training for single mothers of children with ADHD. Journal of Clinical Child and Adolescent Psychology, 38(2), 206-218.

D'Onofrio, B., \& Emery, R. (2019). Parental divorce or separation and children's mental health. World Psychiatry, 18(1), 100-101.

Du, H., Li, X., Lin, D., \& Tam, C. C. (2015). Collectivistic orientation, acculturative stress, cultural selfefficacy, and depression: A longitudinal study among Chinese internal migrants. Community Mental Health Journal, 51(2), 239-248.

Dunn, N., Inskip, H., KendrickT, Oestmann, A., Barnett, J., Godfrey, K., \& Cooper, C. (2008). Does perceived financial strain predict depression among young women? Longitudinal findings from the Southampton Women's Survey. Mental Health in Family Medicine, 5(1), 15-21.

Ennis, E., \& Bunting, B. P. (2013). Family burden, family health and personal mental health. BMC Public Health, 13(255), 1-9. http://www.biomedcentral.com/1471 $-2458 / 13 / 255$

Eriksson, M. (2005). Validity of Antonovsky's sense of coherence scale: A systematic review. Journal of Epidemiology and Community Health, 59(6), 460-466.

Fingerman, K. L. (2017). Millennials and their parents: Implications of the new young adulthood for midlife adults. Innovation Aging, 1(3), 1-16.

Fitriyasari, R., Yusuf, A., Nursalam, N., Tristiana, R. D., \& Nihayati, E. D. (2018). Family members' perspective of family resilience's risk factors in taking care of schizophrenia patients. International Journal of Nursing Sciences, 5(3), 255-261.

Kalil, A. (2003). Family resilience and good child outcomes: A review of the literature. New Zealand: Centre for Social Research and Evaluation, Ministry of Social Development. Te Manatu Whakahiato Ora.

Kim, U., \& Park, Y. (2008). Factors influencing family life-satisfaction among Korean adults: With specific focus on sosial support froum 
spouse, trust of children and selfefficacy. Korean Journal of Psychological and Social Issues, 14(4), 71-101.

Kolak, A. M., Van Wade, C. L., \& Ross, L. T. (2018). Family unpredictability and psychological distress in early adulthood: The role of family closeness and coping mechanisms. Journal of Child and Family Studies, 27(12), 3842-3852.

Michaud, P. A., \& Fombonne, E. (2005). $\mathrm{ABC}$ of adolescence common mental health problems. British Medical Journal, 330,835-838.

González-Gadea, M., Herrera, E., Parra, M., Gómez-Méndez, P., Báez, S., Manes, F., \& Ibáñez, A. (2014). Emotion recognition and cognitive empathy deficits in adolescent of fenders revealed by context-sensitive tasks. Frontiers in Human Neuroscience, 8, 1-11.

Gyamfi, P., Walrath, C., Burns, B. J., Stephens, R. L., Geng, Y., \& Stambaugh, L. (2009). Family education and support services in systems of care. Journal of Emotional and Behavioral Disorder, 18(1), 14-26.

Hasanah, U., Susanti, H., \& Panjaitan, R. U. (2019). Family experience in facilitating adolescents during selfidentity development in exlocalization in Indonesia. $B M C$ Nursing, 18 (Suppl. 1).

Hoagwood, K. A., Cavaleri, M. A., Olin, S. S., Burns, B. J., Slaton, E., Gruttadaro, D., \& Hughes, R. (2010). Family support in children's mental health: A review and synthesis. Clinical Child and Family Psychology Review, 13(1) 1-45.
Kim, J. Y., McHale, S. M., Counter, A. C., \& Osgood, D. W. (2007). Longitudinal linkages between sibling relationships and adjustment from middle childhood through adolescence. Developmental Psychology, 43(4); 960-973.

Konaszewski, K., Kolemba, M., \& Niesiobedzka, M. (2019). Resilience, sense of coherence and self-efficacy as predictors of stress coping style among university students. Current Psychology, $1-11$. doi:10.1007/s12144-019-00363-1

Luecken, L. J., \& Gress, J. L. (2010). Early adversity and resilience in emerging adulthood. In J. W. Reich, A. J. Zautra, \& J. S. Hall, Handbook of adult resilience (pp. 238-257). New York, US: The Guilford Press.

Luthar, S. S. (2006). Resilience in development: A synthesis of research across five decades. In D. Cicchetti, \& D. J. Cohen (Eds.), Developmental psychopathology: Risk, disorder, and adaptation (pp. 739-795). New York: Wiley.

Masten, A. S. (2018). Resilience theory and research on children and families: Past, present, and promise. Journal of Family Theory and Review, 10(1), 12-31. doi:10.1111/jftr.12255

Merikangas, K. R., He, J. P., Burstein, M., Swanson, S. A., Avenevoli, S., Cui, L., ... Swendsen, J. (2010). Lifetime prevalence of mental disorders in US adolescents: Results from the National Comorbidity StudyAdolescent Supplement (NCS-A). Journal of American Academy of Child and Adolescent Psychiatry, 49(10), 980-989.

Myklestad, I., Røysamb, E., \& Tambs, K. (2012). Risk and protective factors 
for psychological distress among adolescents: A family study in the Nord-Trøndelag Health Study. Social Psychiatry and Psychiatric Epidemiology, 47(5), 771-782. doi: 10.1007/s00127-011-0380-X.

O’Rourke, E.J., Halpem, L.F., \& Vaysman, R. (2018). Examining the relations among emerging adult coping, executive function, and anxiety. Emerging Adulthood. doi:10.1177/2167696818797531

Papalia, D. E., Olds, S. W., \& Feldman, R. D. (2009). Human development: Perkembangan manusia. Jakarta: Salemba Humanika

Ragger, K., Hiebler-Ragger, M., Herzog, G., Kapfhammer, H. P., \& Unterrainer, H. F. (2019). Sense of coherence is linked to post-traumatic growth after critical incidents in Austrian ambulance personnel. BMC Psychiatry, 19(89).

Richardson, T., Elliot, P., Roberts, R., \& Jansen, M. (2017). A longitudinal study of financial difficulties and mental health in a national sample of British undergraduate students. Community Mental Health Journal, 55(3), 344-352.

Roest, A. M., Dubas, G. S., \& Gerris, J. R. (2009). Value transmissions between fathers, mothers, and adolescent and emerging adult children: The role of the family climate. Journal of Family Psychology, 23(2), 146-155.

Ryan, R., O'Farelly, C., \& Ramchandani, P. (2017). Parenting and child mental health. London Journal of Primary Care, 9(6), 86-94.

Ryff, C. D. (2014). Psychological wellbeing revisited: Advances in the science and practice of eudaimonia.
Psychotherapy and Psychosomatics, 83, 10-28.

Ryff, C. D., \& Singer, B. H. (2006). Best news yet on the six-factor model of well-being. Social Science Research, 35, 1103-1119.

Streb, M., Haller, P., \& Michael, T. (2014). PTSD in paramedics: Resilience and sense of coherence. Behavioural and Cognitive Psychotherapy , 42(4), 452-463.

Ungar, M. (2013). Resilience, trauma, context, and culture. Trauma Violence Abuse, 14(3), 255-66.

Valdez, C. R., Chavez, T., \& Woulfe, J. (2012). Emerging adults' lived experience of formative family stress: The family's lasting influence. Qualitative Health Research, 23(8), 1089-1102.

Valdez, C. E., Lim, B. H., \& Parker, C. P. (2015). Positive change following adversity and psychological adjustment over time in abused foster youth. Child Abuse Negl, 48, 80-91.

Veronese, G., \& Pepe, A. (2014). Sense of coherence mediates the effect of trauma on the social and emotional functioning of Palestinian health providers. The American Journal of Orthopedic, 84(5), 597-606.

Walsh, F. (2003). Family resilience: A framework for clinical practice. Family Process, 42(1), 1-18.

Wood, D., Crapnell, T., Lau, L., Bennett, A., Lotstein, D., Ferris, M., \& Kuo, A. (2018). Emerging adulthood as a critical stage in the life course. In N. Halfon, C. Forrest, R. Lerner, \& E. Faustman, Handbook of Life Course 
Perception of family hurdles among emerging adults:

A preliminary study about resilience in Indonesian family

Health Development (pp. 123-143).

Springer. 